\title{
Landsat Image Analysis for Open Spaces Change Monitoring to Temperature Changes in Semarang City
}

\author{
Satya Budi Nugraha \\ Department of Geography \\ Universitas Negeri Semarang (UNNES) \\ Semarang, Indonesia \\ Corresponding email: satyabnugraha@mail.unnes.ac.id \\ Wahid Akhsin Budi Nur Sidiq \\ Department of Geography \\ Universitas Negeri Semarang (UNNES) \\ Semarang, Indonesia \\ Fahrudin Hanafi \\ Department of Geography \\ Universitas Negeri Semarang (UNNES) \\ Semarang, Indonesia
}

\begin{abstract}
Land use change in urban areas could not be avoided as consequence of land requirement incensement. The high density of developed land in the central city have pushed the development towards the periphery. This article examines the result of Landsat image analysis using remote sensing (RS) and geographic information system (GIS) technology to monitor green open spaces change to temperature changes in Semarang. Data source which used in this study are Landsat 5 Image in 2003, and Landsat 8 Image in 2015. This uses multispectral classification method with a supervised approach to get land use condition serially (time series). Surface temperature processed based on radiance value in band 6 of Landsat 5 and the value in band 10 and 11 of Landsat 8 TIRS. Temperature changes were seen quite significant in the west side of Semarang City, include Ngaliyan District, Mijen District and Gunungpati District. The change occurs in an average range of $20.75^{\circ} \mathrm{C}$ to $22.07^{\circ} \mathrm{C}$. Along with the temperature changes, based on image analysis result showed that green open spaces in all of three districts were decreased from $48.75 \mathrm{~km} 2$ to $22.98 \mathrm{~km} 2$. In general, the green open spaces change throughout Semarang City from $15.28 \%$ to $9.91 \%$ within a period of 12 years (2003-2015).
\end{abstract}

Keywords-Landsat image, green open space, temperature changes

\section{INTRODUCTION}

Climate change becomes recently interesting discussed issue throughout the world. It was the implication of unstable atmosphere in absorbing thermal radiation from the Sun and carbon emission, which affected to incensement of global temperature (global warming). That condition implies to temperature, weather, and air circulation. It also created natural anomalies. In Indonesia, climate change phenomenon frequently occurred in the big cities with high development intensity, e.g. Jakarta, Medan, Surabaya, Bandung, and Semarang. Urban area deal with different impacts of climate change and disaster is one of them. These impacts include raising rainfall intensity which drives to flood, raising sea level which drives to tidal flood, decreasing of water surface quality, and raising the temperature of the local area (Urban Heat Island). It will affect social and economic community activities directly or indirectly, and a region susceptibility toward the phenomenon.

Urban Heat Island (UHI) phenomenon could be observed through satellite image with particular processing method (C. $\mathrm{Li}$, 2014). Generally, UHI occurred due to the negative impact of urbanization to the environment. Especially a consequence of pollution escalation and physical or chemical modification to the atmosphere and land use. Accumulation of urbanization impacts was considered as UHI triggered factor, which defined as raising air temperature in built areas that create "warm islands" formation among "the cold oceans" that represent low air temperature around the warm areas (P. Dobrovolný, 2013), (G. Ganbat, 2013).

\section{METHOD}

The UHI phenomenon could be determined as one of the indicators that there was significant land use change in the urban area, compare to urban-fringe. Semarang nowadays has rapid changed, not only in the city center (urban area) but also in its suburban. It was caused by the increasing number of the resident and their various activities. In this study, the researcher would utilize image processing technology to discover UHI phenomenon in Semarang. Then, the collected data was 
compared to appropriate parameters from literature in order to formulate guidance of green open space planning in Semarang.

\section{A. Data Collection Method}

Data collection method in this study was using the following method:

\section{- Documentation Method}

Documentation is a technique of data collection by collecting passed documents. It could be writing documents, image, or someone's monumental work (M Mogalakwe, 2006). In this case, researcher use data from the Central Bureau of Statistic (BPS of Semarang City) and Meteorology, Climatology and Geophysics Agency (BMKG of Central Java).

\section{- Survey}

The survey was conducted in order to verify the data accuracy from image satellite processing of land use and existing surface temperature of Semarang.

- Satellite Image Interpretation

Satellite image interpretation was conducted digitally using multispectral classification method in order to have land use imagery in 2005 and 2015. The image processing then performed using an algorithm to obtain data associated with surface temperatures in 2005 and 2015 in the study location.

\section{B. Data Analysis Method}

Data analysis method which used in this study was qualitative descriptive analysis. Satellite image processing results were compared with field data and corresponding appropriate parameters in order to formulate guidance of green open spaces planning in urban areas. It also conducted a spatial quantitative study using pattern comparison analysis. This model is commonly found in the complex spatial analysis. The relationship strength showed by coefficient value, while the influence direction indicated by positive or negative values of the coefficient.

\section{FINDING AND DISCUSSION}

\section{A. Land Cover of Semarang}

Based on data processing of Landsat 5 and Landsat 8 which recorded Semarang and surrounding areas, the land cover of Semarang could be classified into ten classes, as presented in Table 1. In 2003, the dominant land cover in the study location is moor which mostly spread in District Gunungpati, District Mijen, District Ngaliyan, and District Genuk with area 111.01 $\mathrm{km}^{2}$, or about $28.61 \%$. The next dominant land cover class is a residential building which thronged the north and the east part of Semarang with coverage area $99.75 \mathrm{~km}^{2}$, or about $25.70 \%$. Another fairly large land covers are forest and rice fields 38.32 $\mathrm{km}^{2}$ and $30.51 \mathrm{~km}^{2}$. These both types of land cover clustered in one area. Industrial land cover dominates the coastal area of Semarang with coverage $21.46 \mathrm{~km}^{2}$. Semarang industrial activity growth rapidly as the impact of Tanjung Emas Port which is the entry-exit of goods to Central Java Province from various islands in Indonesia. Furthermore, the type and coverage area of Semarang land cover in times series presented below.

TABLE 1. COMPARISON SIZE OF LAND COVER OF SEMARANG

\begin{tabular}{|c|c|c|c|c|c|}
\hline \multirow[b]{2}{*}{ No } & \multirow{2}{*}{$\begin{array}{c}\text { Land Cover } \\
\text { Class }\end{array}$} & \multicolumn{2}{|c|}{2003} & \multicolumn{2}{|c|}{2015} \\
\hline & & $\begin{array}{c}\text { Large } \\
\left(\mathbf{k m}^{2}\right)\end{array}$ & $\%$ & $\begin{array}{c}\text { Large } \\
\left(\mathbf{k m}^{2}\right)\end{array}$ & $\%$ \\
\hline 1 & Forest & 38.32 & 9,87 & 12.27 & 3,16 \\
\hline 2 & $\begin{array}{l}\text { Industrial } \\
\text { Building }\end{array}$ & 21.46 & 5,53 & 14.92 & 3,84 \\
\hline 3 & Roads & 14.26 & 3,67 & 25.29 & 6,51 \\
\hline 4 & Sea & 11.44 & 2,94 & 23.55 & 6,06 \\
\hline 5 & Sand & 14.43 & 3,72 & 8.18 & 2,10 \\
\hline 6 & $\begin{array}{l}\text { Settlement } \\
\text { Building }\end{array}$ & 99.75 & 25,70 & 94.07 & 24,24 \\
\hline 7 & $\begin{array}{l}\text { Green Open } \\
\text { Space }\end{array}$ & 19.87 & 5,12 & 25.02 & 6,44 \\
\hline 8 & Rice Field & 30.51 & 7,86 & 37.84 & 9,75 \\
\hline 9 & Shrub & 26.94 & 6,94 & 54.67 & 14,09 \\
\hline 10 & Moor & 111.01 & 28,61 & 92.18 & 23,75 \\
\hline & Sum & 387.99 & 100 & 387.99 & 100 \\
\hline
\end{tabular}

Monitoring changes of land cover of Semarang conducted over a time span of 12 years from $2003 \mathrm{~s} / \mathrm{d} 2015$ with the data source satellite images Landsat 5 and Landsat 8 which recorded Semarang and surrounding areas. In general, it could be described that during the time span of 12 years showed that land cover vegetation consisting of forest and green open space experienced significant changes wherein 2003 the vegetation area in Semarang reached $58.19 \mathrm{~km}^{2}$ and has declined to be $37.29 \mathrm{~km}^{2}$. The decline in vegetation areas has occurred due to land use changes which turned into built area (residential and industry). It caused by high population growth in Semarang and added with migrants from other regencies/cities in Central Java Province which aim to work and have higher education, thus triggers the development in various areas of Semarang. At this time the vegetation area dominated at the south and west part of Semarang (District Gunungpati, Mijen, and Ngaliyan), while in the urban areas, vegetation cover exists on parks, roads border, rivers borders, and others.

The incensement of built area size not only concentrated in urban areas but also has spread to the periphery area. It happened due to a reason that Semarang city center has already a dense area, therefore the development diverted to suburban. A few years back, development of service building has grown rapidly, e.g. hotels, supermarkets and various residential buildings for the elite and the middle-bottom class. The spatial distribution of land cover in each year presented in Figure 1 and Figure 2. 


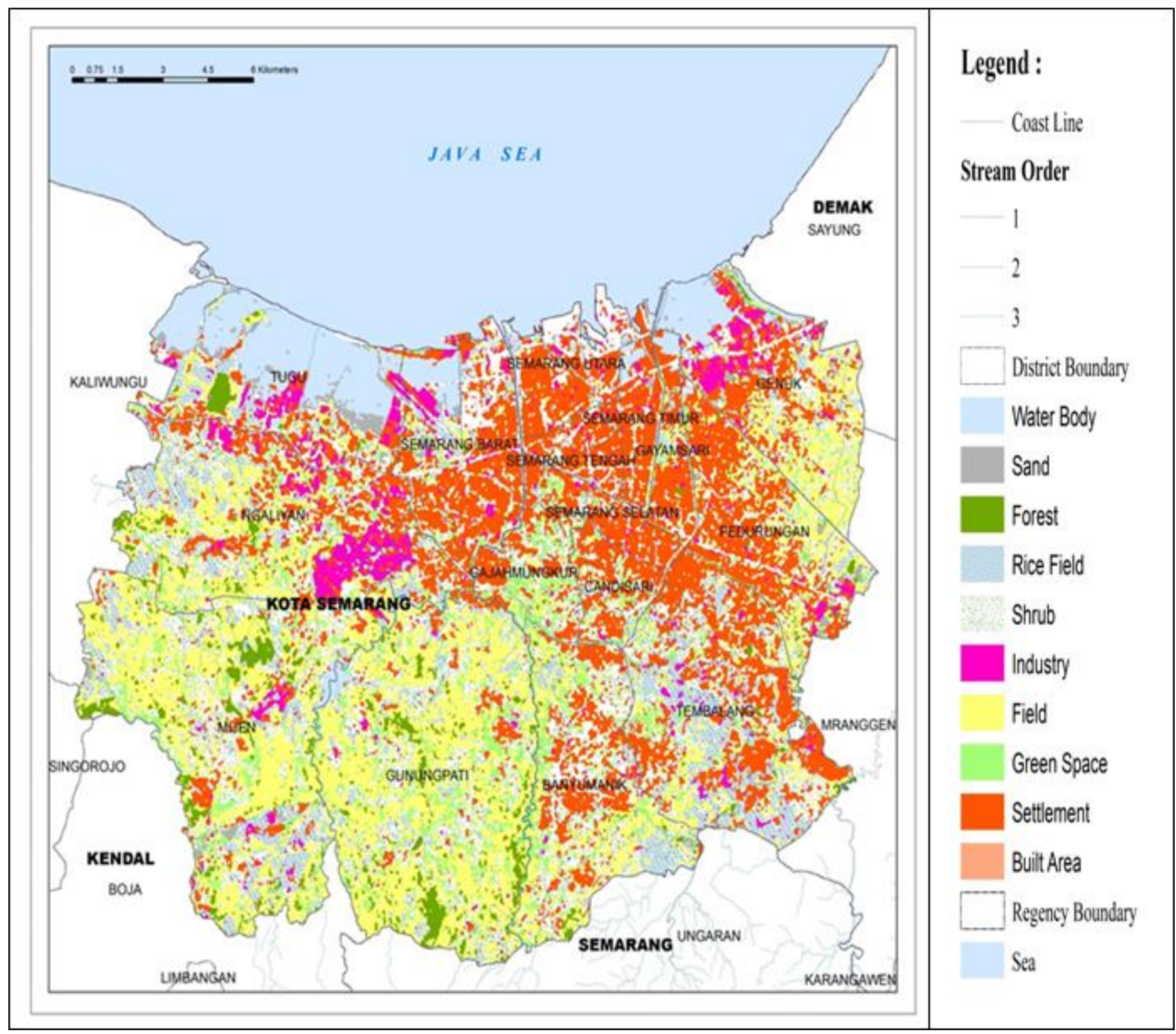

Fig. 1. Land Cover of Semarang in 2003 


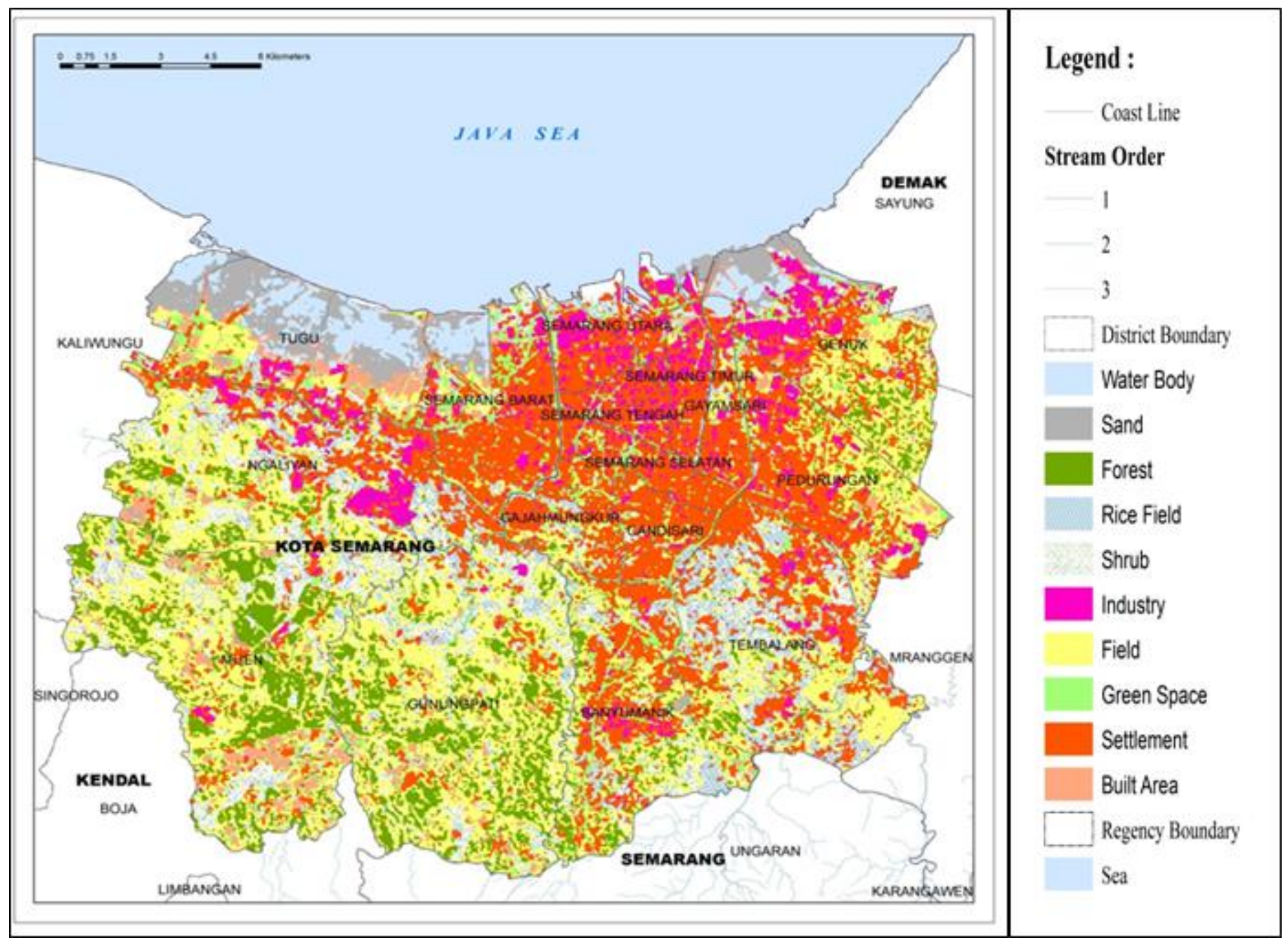

Fig. 2. Land Cover of Semarang in 2015

\section{B. Surface Temperature Algorithm}

Overview of site surface temperature was obtained from thermal band processing of Landsat 5 (2003) and Landsat 8 (2015). Processing in different years was conducted to determine the changes that occurred to the study site surface temperature during that period. On Landsat 5 image of 2003 , the surface temperature acquired from thermal bands which found on channel 6 with a wavelength 10.40-12.50 micrometres. On Landsat 8 image of 2015 , it recorded by Thermal Infrared Sensor (TIRS) consisting of channels 10 and 11 with a wavelength 10.60-11.19 micrometres and 11.5012.51 micrometres.

Processing surface temperature in each image conducted using an algorithm referred from previous studies (Y. Xu, 2011; Y. A. Yusuf, 2014). The processing started from conversion process of Digital Number (DN) of the thermal band into spectral radiance $(\mathrm{L} \lambda)$ values by the following equation:

Radiance $(\mathrm{L} \lambda)=($ gain $\times \mathrm{DN})+$ offset
Equation (1) gain means Constanta with value 0.05518, then offset means Constanta with value 1.2378. This equation was simplification result from following equation:

$$
\mathrm{L} \lambda=\underset{\mathrm{QCALmin}))+\mathrm{Lmin}}{((\mathrm{Lmax}-\mathrm{Lmin})} /(\mathrm{QCALmax}-\mathrm{QCALmin}) \times \text { (QCAL- }
$$

Equation (2) QCALmin value is 1, QCALmax value is 255, and QCAL means Digital Number (DN). While Lmin and Lmax are spectral radiance which becomes temperature. Spectral radiance conversion into temperature could use thermal band image value. It could be converted into physical variables with assuming that emissions are one. Spectral radiance conversion equation is as follows:

$$
\mathrm{T}=\mathrm{K} 2 / \ln (\mathrm{K} 1 / \mathrm{L} \lambda+1)
$$

Equation (3) T means temperature; K1 means Constanta in watt with value 666.09 for ETM+ and 607.76 for TM; K2 means Kelvin Constanta with value 1282.71 for ETM+ and 1260.56 for TM. 


\section{Analysis of Raising Temperature}

Results of the primary data inventory consist of maximum, minimum, and average temperature. The data were distinguished in each land cover at every single sampling time. This means that the land cover response toward temperature rise for a certain time. However, because of measurement time constraints, not all the time measurement and types of land cover could be represented. Therefore the researcher was grouping data so that the fluctuation can be seen. In order to review general distribution pattern, some similar land cover classified in a special cover land, i.e. field (moor and garden), settlement and built area (residential and industry), shrub, forest and well canopy (forest, green open space, shrub), and wetland (fishpond). Temperature distribution toward time and land cover shown at this following figure.

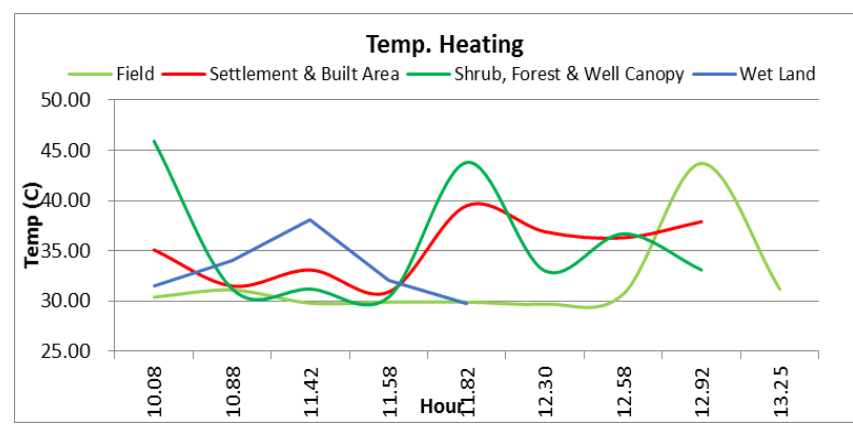

Fig. 3. Increased Temperatures Toward Time in Multiple Land Cover

Although the data homogeneity and distribution was not complete, but it showed fluctuations in some cases of land cover. Data showed that settlement and built area has a shorter warm-up time compare to the field. The field has heating time longer, from normal to maximum temperature require about 3 hours, while the settlement and built area only took two hours for rising to maximum temperature. The previous curve separated as follows figure.

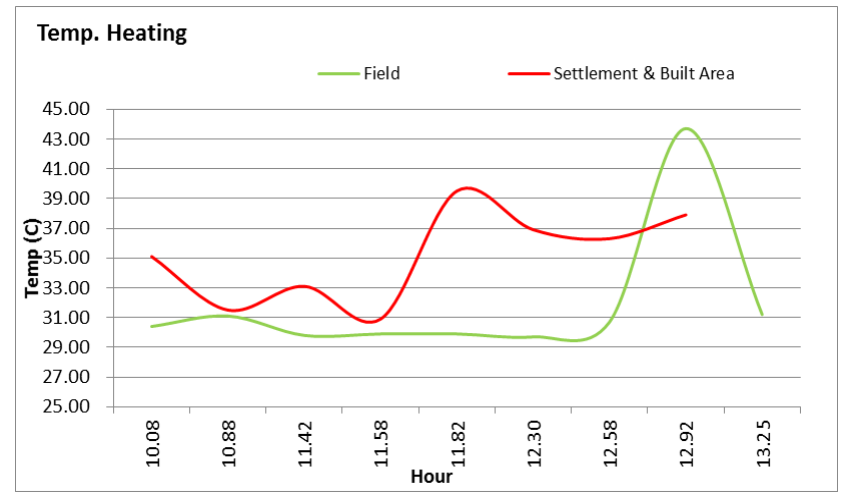

Fig. 4. Increased Temperatures Toward Time in Field, Settlement and Built Area

Based on Landsat imagery analysis and surface temperature algorithm, temperature change patterns from 2003 to 2015 could be seen. Data showed that there was a significant correlation between settlement and built area incensement sizes toward surface temperature. It means that the cities growth leads to increased temperature (urban heat) either qualitatively or quantitatively. The following figure shows the pattern change of settlement and built area in a time period 2003-2015 toward surface temperature.

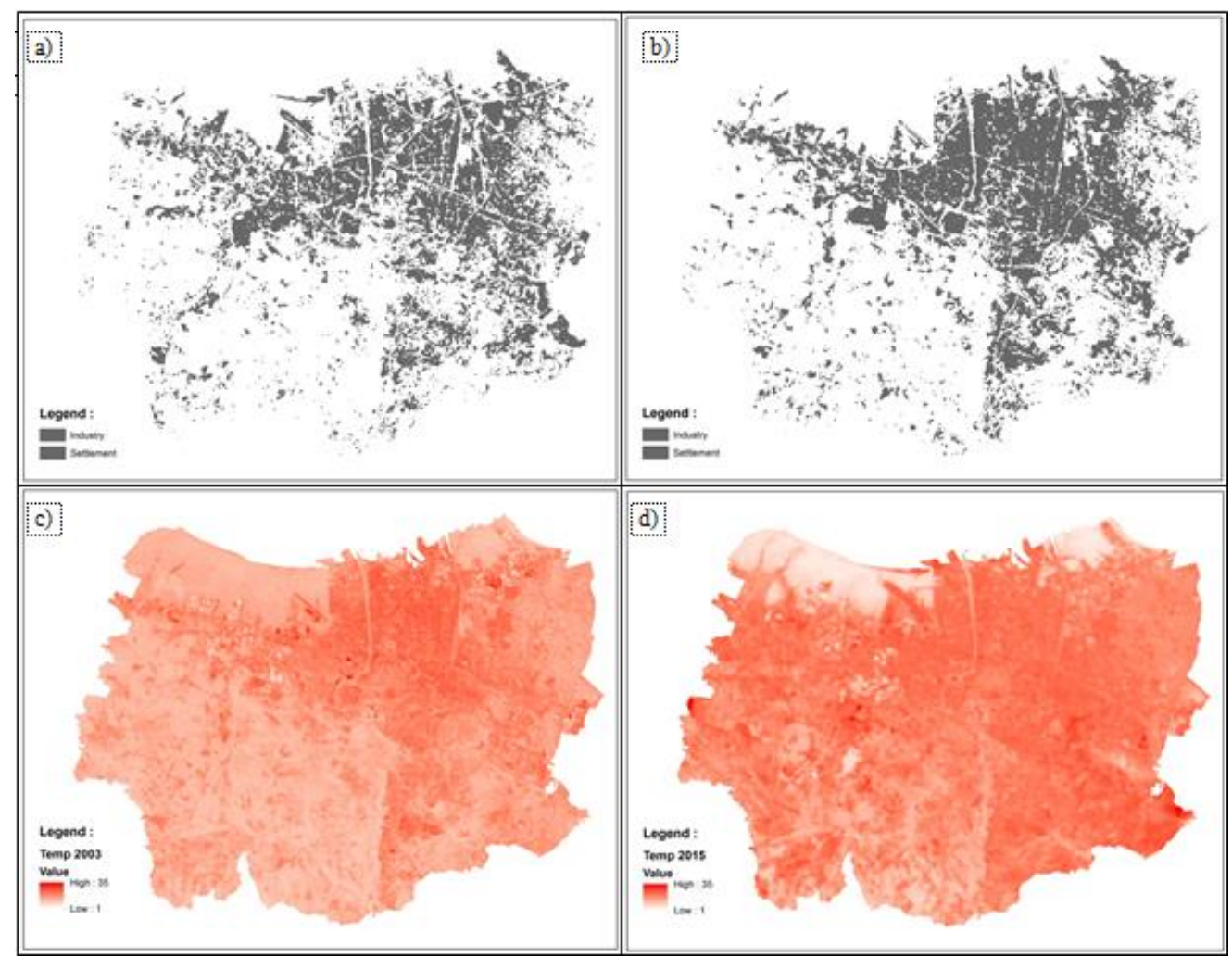

Fig. 1. a) Comparison of Settlement 2003, b) Comparison of Settlement 2015, c) Built Area Development Toward Increased Temperature 2003, d) Built Area Development Toward Increased Temperature 2015 
Based on data processing result and statistical analysis (percentage and per land use), then the area temperature could be calculated. Analysis results per pixel of image temperature on land cover showed that in the period 2003-2015 occurred raising temperatures in Semarang, from total area temperature of $20.75^{\circ} \mathrm{C}$ increased to $22.07^{\circ} \mathrm{C}$. Recapitulation detail result of increased temperature change in each land cover shown in the following table.

TABLE 2. REGION TEMPERATURE INCREASED RECAPITULATION IN EACH LAND COVER

\begin{tabular}{|c|c|c|}
\hline Land Cover & $\begin{array}{c}\text { Region } \\
\text { Temperature 2003 } \\
\left({ }^{\mathbf{}} \mathbf{C}\right)\end{array}$ & $\begin{array}{c}\text { Region Temperature } \\
\mathbf{2 0 1 5} \\
\left({ }^{\mathbf{}} \mathbf{C}\right)\end{array}$ \\
\hline Forest & 20.09 & 22.14 \\
\hline Industrial Building & 21.18 & 22.09 \\
\hline Roads & 20.85 & 22.04 \\
\hline Sea & 20.43 & 21.05 \\
\hline Sand & 20.30 & 20.96 \\
\hline Settlement Building & 21.46 & 22.54 \\
\hline Green Open Space & 21.33 & 22.41 \\
\hline Rice Field & 20.81 & 22.50 \\
\hline Shrub & 20.51 & 22.59 \\
\hline Moor & 20.56 & 22.36 \\
\hline Average & $\mathbf{2 0 . 7 5}$ & $\mathbf{2 2 . 0 7}$ \\
\hline
\end{tabular}

\section{CONCLUSIONS AND SUGGESTIONS}

Based on data processing result and analysis could be concluded there was significantly increased the temperature of the urban area of Semarang in 15 years. It indicated a previous land cover change in the form of the open area into built area. However, this could not be used yet as a reference since the temperature input and sun radiation during data recording was not used as a benchmark calibration. Furthermore, any temperature consideration will affix a different temperature was not totally true because the temperature concept as energy which able to spread toward lower temperatures cause the temperature limits on land use were difficult to made. That means the land use limitation is a concrete boundary, while the temperature limits are a gradual or continuous boundary. This indicated by the presence of several anomalies of temperature changes to the unit area $\left(\mathrm{km}^{2}\right)$ of each land cover, as shown in the following table.

TABLE 3. COMPARISON OF TEMPERATURE CHANGES PER UNIT AREA

\begin{tabular}{|c|c|c|c|c|c|}
\hline \multirow{3}{*}{$\begin{array}{l}\text { Land } \\
\text { Cover }\end{array}$} & \multicolumn{2}{|c|}{2003} & \multicolumn{2}{|c|}{2015} & \multirow{3}{*}{$\begin{array}{c}\text { Temp. } \\
\text { Change/ } \\
\text { Large } \\
\left({ }^{\circ} \mathbf{C} / \mathbf{K m}^{2}\right)\end{array}$} \\
\hline & Large & Temp. & Large & Temp. & \\
\hline & (Km2) & $\left({ }^{\circ} \mathbf{C}\right)$ & $(\mathrm{Km} 2)$ & $\left({ }^{\circ} \mathbf{C}\right)$ & \\
\hline Forest & 38.32 & 20.09 & 12.27 & 22.14 & 0.05 \\
\hline $\begin{array}{c}\text { Industrial } \\
\text { Building }\end{array}$ & 21.46 & 21.18 & 14.92 & 22.09 & 0.04 \\
\hline Roads & 14.26 & 20.85 & 25.29 & 22.04 & $(0.05)$ \\
\hline
\end{tabular}

\begin{tabular}{|c|c|c|c|c|c|}
\hline Sea & 11.44 & 20.43 & 23.55 & 21.05 & 0.00 \\
\hline Sand & 14.43 & 20.30 & 8.18 & 20.96 & 0.00 \\
\hline $\begin{array}{c}\text { Settlement } \\
\text { Building }\end{array}$ & 99.75 & 21.46 & 94.07 & 22.54 & 0.07 \\
\hline $\begin{array}{c}\text { Green } \\
\text { Open } \\
\text { Space }\end{array}$ & 19.87 & 21.33 & 25.02 & 22.41 & $(0.08)$ \\
\hline Rice Field & 30.51 & 20.81 & 37.84 & 22.50 & $(0.14)$ \\
\hline Shrub & 26.94 & 20.51 & 54.67 & 22.59 & $(0.05)$ \\
\hline Moor & 111.01 & 20.56 & 92.18 & 22.36 & 0.06 \\
\hline
\end{tabular}

In an ideal condition, any decrease in forest area would impact to increased temperature, as shown in the table that each $1 \mathrm{Km}^{2}$ reduced of forest area, the temperature would rise $0.05{ }^{\circ} \mathrm{C}$, but this is not always true. Anomalies in some reduction of another land cover total area toward temperature changes are difficult to predict.

Limitation of the study need to be improved in order to achieve better results, it should be:

- Consistent and sequential measurement hours

- Focus on homogeneous land cover

- Raster-based modelling of temperature distribution with matrix approach and nearest neighbour analysis

- Input existing temperature radiation at the time of recording

- Image calibration of synthetic measured temperature

\section{REFERENCES}

[1] C. Li, D. Shen, J. Dong, and J. Yin, "Monitoring of urban heat island in Shanghai, China, from 1981 to 2010 with satellite data," Arab J. Geosci., vol. 7, pp. 3961-3971, 2014.

[2] P. Dobrovolný, "The surface urban heat island in the city of Brno ( Czech Republic ) derived from land surface temperatures and selected reasons for its spatial variability," Theory Appl. Climatol., vol. 112, pp. 89-98, 2013.

[3] G. Ganbat, J. Han, Y. Ryu, and J. Baik, "Characteristics of the Urban Heat Island in a High-Altitude Metropolitan City," Asia-Pacific J. Atmos. Sci., vol. 49, no. 4, pp. 535-541, 2013.

[4] M. Mogalakwe, "The Use of Documentary Research Methods," African Sociol. Rev., vol. 10, no. 1, pp. 221-230, 2006.

[5] Y. Xu, Z. Qin, and H. Wan, "Spatial and Temporal Dynamics of Urban Heat Island and Their Relationship with Land Cover Changes in Urbanization Process : A Case Study in Suzhou, China," J. Indian Soc. Remote Sens., vol. 38, no. 4, pp. 654-663, 2011.

[6] S. Yildiz and M. F. Doker, "Monitoring urban growth by using segmentation-classification of multispectral Landsat images in Izmit, Turkey," Environ. Monit. Assess., vol. 188, p. 393, 2016.

[7] Y. A. Yusuf, B. Pradhan, and M. O. Idrees, "Spatio-temporal Assessment of Urban Heat Island Effects in Kuala Lumpur Metropolitan City Using Landsat Images," J. Indian Soc. Remote Sens., vol. 42, no. 4, pp. 829-837, 2014. 